\title{
Study on Criminal Response Dilemma of China's Environmental Pollution Crime in the Context of Risk Society*
}

\author{
Demin Yang \\ Baicheng Normal College \\ Baicheng, China
}

\begin{abstract}
Under the background of risk society, environmental pollution crimes show a normal development trend. In recent years, the criminal law theorists and judicial practitioners in other countries in the world and in China have adopted the strict criminal law sanctions to gradually pay attention to the governance and rectification of pollution crimes. This paper takes the current social risk background as a perspective to deeply analyze the status and characteristics of China's environmental pollution. The method of combining the historical development of environmental criminal legislation in China with the perspective of comparative law was elaborated, revealing that there are indeed some problems in the current criminal legislation about environmental crimes in China. It will provide reference for the improvement of China's environmental crime legislation.
\end{abstract}

Keywords-risk society; environmental pollution crime; criminal legislation

\section{INTRODUCTION}

As a late-model modern country, China has quickly entered the risk society in just a few decades. This rapid transformation has forced us to face many problems that Western societies already face, such as homogeneity or homology. Under this background, the theory of risk society has taken root in China's criminal law theory circle and has just begun to flourish, especially in recent years. Since then, China's environmental pollution has become increasingly serious. It has seriously damaged people's lives, health and property safety and prompted the public and the government to make up their minds to improve the environment. Environmental criminal law theory has also emerged. At present, the legal system with criminal law as the main content has become China's basic social governance model. However, whether any model of social governance is successful depends, in the final analysis, to see whether we can bring happiness and well-being to members of society. In the new era, how to manage environmental crimes, adhere to the harmonious coexistence of humans and nature and promote sustainable social development have become social

*[Fund Project] Jilin Province Education Science "12th Five-Year Plan" key research findings, project approval number: ZD15104. Jilin Provincial Department of Education "Thirteenth Five-Year Plan" social science project in 2018: "research on the issue of criminal regulation of environmental pollution in the view of risk society" [JJKH20180319SK] issues that the government has yet to solve. Report of the 19th National Congress of the Communist Party of China states that "building an ecological civilization is a millennium strategy for sustainable development of the Chinese nation. In this regard, we must implement the strictest system of ecological environmental protection, form green development methods and lifestyles and firmly take the path of civilized development with the development of production, affluence in life and sound ecology, build a beautiful China and create a favorable production and living environment for the people. Global ecological security contributes.

\section{REALISTIC DESCRIPTION OF THE RISK OF ENVIRONMENTAL POLLUTION}

Protecting the environment is China's basic state policy and is an important part of the sustainable development strategy. In the new era, China's economic construction has made major achievements and remarkable achievements have been made in the construction of ecological civilization. However, the issue of environmental pollution is still not slack and ecological and environmental protection also has a long way to go. In this regard, legal system construction should be the starting point for all work. As early as a hundred years ago, Marx pointed out: "If civilization develops spontaneously rather than consciously, it will leave its own desert." Facing the "fog", grassland desertification, water pollution and other shocking environmental pollution as an issue, the criminal law, which combines the most stringent and modest, should be attacked in a timely manner and exert its deterrent role in punishing environmental pollution. This has become an indisputable fact. "There is law to follow" is the premise of any rule of law. In fact, in recent years, China's criminal law has made major revisions to environmental pollution crimes, gradually highlighting the protection and importance of environmental law. For example, the "Criminal Law" of 1997 absorbed the provisions of the affiliated criminal law, added the crime of major environmental pollution accidents (Article 338), the crime of illegally disposing of imported solid waste, the crime of unauthorized import of solid waste (Article 339) and the crime of misconduct of environmental supervision (No. 408). The "Criminal Law Amendment (8)" adjusted the 
major environmental pollution accident to the crime of environmental pollution. In addition, the Supreme People's Court issued relevant judicial interpretations with respect to environmental pollution crimes in 2006, 2013 and 2016, and improved the relevant criminal legislation on environmental pollution crimes. Despite this, in recent years, there have been some new situations and problems in environmental pollution crimes, such as the signs of industrialization of hazardous waste crimes, difficulty in obtaining evidence for atmospheric pollution crimes and the existence of criminal regulations that falsified or forged automatic monitoring data and destroyed environmental quality monitoring systems. Controversy and so on. Faced with this realistic background, China's current criminal legislation with respect to environmental crimes still has many defects and deficiencies in terms of legislative concepts, legislative styles, scope of charges and penalties. It is impossible to fundamentally prevent environmental crimes from being polluted, does not meet the requirements of ecological laws and cannot adapt to the current state of judicial demand. The criminal law legislation lags the crime situation. It is a social phenomenon that is still difficult to eliminate. The environmental criminal law is also the case. The important thing is to identify the "root cause" and thus "prescribe the right medicine".

\section{THE EVOLUTION OF THE CRIMINAL LEGISLATIVE IDEA OF ENVIRONMENTAL POLLUTION CRIME}

China's existing criminal law criminal norms concerning environmental pollution are established based on the interpenetrative value concept of traditional environmental criminal law. As we all know, "anthropocentrism" is the world concept and mode of thinking that dominates the industrial civilization era. It advocates that the natural environment is the property of mankind himself and the role of the environmental criminal law is to meet the needs of mankind's own interests, to conquer and transform the natural environment in accordance with mankind's own goals, human interests are paramount and only the person and property closest to mankind. When the interests are infringed, the criminal law will be punished. This legislative concept ignores the close interdependence between human society and the natural environment and the characteristics of the natural environment that adversely affect human society. The consequences are a series of serious environmental problems. The dynamic balance of the ecological environment system is broken and the human society is jeopardized. The stable and sustainable development. With the deterioration of environmental pollution in various countries around the world and the "easiness of individual forces" in various governance measures, scholars are increasingly aware that humans must break with "anthropocentrism" in the era of industrial civilization and recognize that human ecological interests are the primary benefits. Rather than the only interest, therefore, advocates that the purely ecological theory of law gains momentum, purely ecological theory of Legal protection benefits (also known as environmental center doctrine of legal theory) that the protection of environmental crime benefits is the ecological environment itself (water, Soil, air and other environmental interests (animals, plants). Scholars of China's purely economist theory of law theory pointed out: "Before this revision, the legislators established environmental crimes based on the values of anthropocentrism, which is the traditional concept of conservation of Legal protection benefits...through this revision. It shows that the legislator's legislative idea of environmental crime has changed from the anthropocentrically values of the past to the value of the environment-based concept. Under the legislative concept of the environment-based principle, legislators no longer regard man as the master of all things--people. It is the measure of everything and 'all things are subject to the needs of the people'. Therefore, when formulating laws, it abandoned the narrow anthropocentric thinking model and treated people as an integral part of the environment, not just the environment. Users... The environmental resources have become the objects that the criminal law has to protect and they have the independent significance and value of the criminal law. The reason why environmental crimes are established is to protect the environment itself, not to punish the environment. Human life, health and property damage." Therefore, regarding the protection of environmental crimes, the current domestic and foreign criminal law The theory mainly involves the debate between the pure human center's Law Protection Benefits and pure ecology's legal theory and eclecticism (ecological human center theory of Law Protection Benefits). Although the Criminal Law Amendment (8) of China's Criminal Law in 2011 amended and improved the criminal law provisions for environmental pollution crimes, it does not include the specific expression of "serious pollution of the environment" or judicial practice Regarding the determination of "environmental pollution crimes", it is difficult to determine whether it is to continue to adopt the purely human center of legal interests or to adopt purely ecological legal ideas. On June 17, 2013, Article 1 of the "Interpretation of Several Issues Concerning the Application of Law on Handling Criminal Cases of Environmental Pollution" jointly issued by the Supreme People's Court and the Supreme People's Procuratorate stipulated 14 items of "serious" In the case of "pollution of the environment", the first five items are not the result of property loss, personal injury or death. Supreme People's Court, Supreme People's Procuratorate Article 1 of the Interpretation of Several Issues Concerning the Application of Law in Handling Criminal Cases of Environmental Pollution (hereinafter referred to as "2016 Interpretation") of December 23, 2016, stipulates 18 cases of "serious environmental pollution". Among them, the first eight items are not provisions on the results of property loss, personal injury or death. The latter two items of the two interpretations deal with the consequences of property loss and personal injury. Obviously, different understandings of the protection of Legal protection benefits will lead to different evaluations of the provisions of judicial interpretation and will also affect the judicial determination of the crime of environmental pollution. How to accurately position the Law Protection Benefits that have been infringed upon by environmental pollution crimes is related to the creation of an ecological civilization that is compatible with the survival and development of humankind in the $21 \mathrm{st}$ 
century and promotes the sustainable development of human society.

\section{ANALYSIS OF THE CRIMINAL DILEMMA OF ENVIRONMENTAL POLLUTION CRIME IN CHINA}

\section{A. Analysis of the Predicament of Environmental Pollution Conviction}

1) Subjective responsibility for environmental pollution offenders blur: The sin dispute is that the "Criminal Law Amendment (8)" will punish the original conditions for the establishment of a crime-"serious consequences of major environmental pollution accidents, resulting in major public and private property losses or personal injury". "The crime was also changed to "pollution of the environment." Therefore, although general information still insists that the crime of environmental crimes is a form of fault, it is effectively said that the form of sin has been changed from negligent to intentional. In addition, there are different claims such as dual guilty excuse, sin form exception and vague $\sin$. It can be said that the legislative amendments have not eliminated the differences in the understanding of the forms of guilt, but have made the debate even fiercer.

In fact, negligent negligence is rarely seen in secondary (long-term or gradual) environmental pollution accidents and the perpetrators' guilty mentality is mostly "knowingly guilty", that is, knowing that the discharge of pollutants is illegal, may or may not Environmental pollution continues to discharge pollutants in the pursuit of economic efficiency.

Is this kind of "perceived crime" mentality intent on the criminal law? Scholars who "deliberately say" undoubtedly have answered this question in the affirmative. However, we should not equate the concept of "beknown to commit crimes" in life with "deliberateness" in criminal law. If you simply understand literally, "knowingly committing an offence" is, of course, "intentional," but the "intentional" in criminal law has a specific direction, that is, "knowing that your actions will endanger the results of society and hope or let it happen." Therefore, what constitutes a crime is intentional crime." The key question then is that "the result of harming society" here is merely the need to recognize that the act of polluting itself "will pollute the environment" or must recognize the 338th criminal environment of the Criminal Code. The "consequences of causing serious environmental pollution accidents resulting in major losses of public and private property or serious personal injuries" as stipulated in the crime of pollution accidents? In other words, the perpetrator recognized the "lesser harm to society" or "general harm to society", while the subtext defined in the article is "seriously endangering the results of society". Which one is the criminal law? What is stated in Article 14 "knowing that his actions will endanger the results of society"?

This doubt led to the fact that most judges in the judicial practice held an evasive attitude toward the crime of environmental pollution. This commitment to the responsibility of polluting the environment will inevitably lead to the crime of misconduct.

2) The miscellaneous objective behavior of environmental pollution crime: Through a detailed comparison of the major environmental pollution accidents in the 1997 Criminal Law and the existing pollution-related crimes, it is not difficult to find that both are guilty of penalties for polluting the environment and there is no second similar crime. The crime of environmental pollution includes a variety of behaviors that pollute the environment and is uniformly covered by one crime. However, after the study of relevant environmental laws abroad and our country's years of governance and environmental practices, we have always believed that a single conviction on a single crime is not very scientific. The reasons are as follows: First, there are different objects that pollute the environment. There are certain differences between different kinds of objects. It is inappropriate to classify them as a single crime. Secondly, the results of damage caused by different pollution-related environmental crimes are different. Reflected in sentencing, it should also be differentiated on the crime; the last is the implementation of different ways of polluting the environment and the use of different mediation, so it reflects the different behavioral characteristics. Summary Three points the author believes that it is not only a single crime to set up the crime of environmental pollution, but also the scientific nature to be confirmed. In addition, after analyzing the different nature of different environmental pollution behaviors, we also conducted more detailed research on the elements of different environmental pollution crimes and found that there are certain differences between the constituent elements. Therefore, a single crime of contaminating the environment can only be said to be an omission by legislators.

\section{B. Penalties and Crimes of Environmental Pollution Crimes Are not Quite Equivalent}

On July 13, 2017, the Supreme People's Court issued an environmental justice development report showing that in the past three years, 2,066 people have been sentenced to six months to one year for environmental pollution, accounting for $50.30 \%$ of all crimes. For 1060 people, accounting for $25.81 \%$, was sentenced to imprisonment of three years to five years, accounting for only $1.31 \%$ of the total number of crimes. This means that most of environmental crimes are sentenced to less than three years. There is a problem that the punishment of environmental resources is generally light, which is actually contrary to the principle of the crimes stipulated in the general provisions of China's criminal law.

First of all, the provisions of the criminal law are lighter and the effect of warnings is not significant. Currently motivated by monetary interests, polluters are usually guilty of luck and they can calculate how much economic benefit can be obtained through pollution discharge. Because the illegal costs are too low, even if they are arrested, the sentence imposed is not long. If they are not caught, they can 
earn high profits and it is worth taking a risk. Sentencing of environmental crimes is too light, which is one of the most important reasons for repeated environmental pollution incidents

Secondly, this penalty is inconsistent with the principle of recidivism in China's criminal law. Contamination of the environment and theft, fraud will also infringe upon the property of others, infringe on public property, even pollute the environment sometimes bring greater economic losses and why sentenced to a lighter sentence. In addition, the crime of environmental pollution not only infringes on people's life and health and property safety, but also invades the ecological environment. The subjective viciousness and social harm are huge. It is more serious than mere property crimes, but the maximum legal penalty for environmental pollution crimes is seven years. The highest legal penalty for property crimes is life imprisonment. Contaminating the environment with serious crimes cannot reach the goal of deterring illegal crimes, but it is also not conducive to cracking down on environmental crimes. At the same time, it is also objectively letting go of environmental pollution behaviors, which eventually leads to frequent environmental pollution incidents.

Finally, there is a single type of penalty. The penalty penalties used in environmental crimes are mainly manifested in the country as principal punishmentsregulation, criminal detention, fixed-term imprisonment and additional punishment-penalty and the principal and additional punishments are used alternately or in combination. It has played a good disciplinary role in cracking down and punishing environmental crimes but compared with the complementary use of non-penalty measures, penalties and qualification punishments adopted by foreign developed countries in environmental pollution legislation, the effect is still not ideal. The most unsatisfactory manifestations are: First, the qualification penalty does not have a definite status in China's pollution and environmental crimes. The specific application simply refers to the deprivation of political rights, which is relatively monotonous and the qualification penalty cannot be applied additionally to the principal punishment. Naturally, the effectiveness will be greatly reduced. Second, there is a lack of complementary use of non-penalty measures in China's criminal legislation on pollution. Non-penalty measures mainly refer to exhortation, repentance, apology, order restitution and deadlines. In other criminal legislations of our country, non-penalty measures are used in an appropriate manner, but they are absent in the criminal legislation on environmental pollution. In addition, non-penalty measures such as exegesis and order restitution are used as a necessary condition for the principal punishment in foreign countries and there is great potential for promotion. In contrast, China's lack of non-penalty measures in legislation and law enforcement appears to be relatively backward.

\section{The Lack of Administrative Law Enforcement of Environmental Pollution Crimes and the Lack of Judicial Supervision and Supervision Mechanisms}

In the July 13, 2017 Supreme Court's release of the Environmental Justice Development Report, it is worth noting that, in the 2016 Environmental Administrative Public Interest Litigation, administrative omission cases accounted for the overwhelming majority and the proportion of cases as class and inaction cases was approximately 1:5.

The report analyzes that this is because the focus of public prosecution actions brought by the PR curatorial organs is to supervise the dereliction of duty and malfeasance of the administrative agencies and it also shows that the phenomenon of "non-action" in environmental law enforcement is more common. In some places, local protectionism has existed for a long time and is prevailing. Local governments and their departments have considered the environmental pollution and its criminal acts relatively insignificant in light of the comprehensive measurement of the interests of its own departments and local economic development.

The geographical white city where the writer lives are located in the northwest of Jilin Province and east of the kerqin grassland. From 2007 to 2014, 21 people, including Wang, a peasant in Tongjie County, Tonghua County, illegally cultivated the cultivated land in the collective grassland of the group, JixiangShengli Village, Tongyu County. By 2015, the total area of illegally reclaimed collective grasslands in Tuanjie Township, Tongyu County was 1931 acres and the vegetation of the local grasslands was severely damaged. This kind of destruction of the grasslands has been able to last so many years, resulting in such a large area of damage and the inaction of the relevant responsible personnel of the Agricultural and Livestock Husbandry Bureau of Tongyu County has an important connection with non-performance of the supervisory duties. The destruction of such a large area of grassland has caused the grassland to save water and protect soil, regulate the climate, improve the environment and maintain the ecological and other important functions. It has not been able to repair the grassland in a short period of time, making grassland evolve into sandy land, semi-fixed with wind erosion sand. The state is predominant, causing sand and dust weather in the Baicheng area to become more and more serious, seriously affecting the ecological environment and human health. The long-term judicial practice shows that China does not lack laws. What is lacking is how to truly implement the contents of laws and regulations into judicial practice. In many cases, it is necessary to sacrifice laws and even break through the provisions of laws for the sake of economic development. It is not uncommon for administrative agencies to resort to single and onepunishment in solving environmental problems. The corruption and laziness of the environmental protection departments have often led to the fear of the companies involved. This makes the existing areas that are already more vulnerable to some ecological environment are faced with a difficult situation. 
At the same time, some administrative law enforcement agencies have adopted selective law enforcement during environmental law enforcement. Judicial organs in the investigation and handling of suspected environmental pollution crime cases of malfeasance, dereliction of duty and other acts, even there are rights trading and other suspected profits to export corruption. In the implementation of environmental pollution problems, law enforcement agencies only transferred a small number of cases that had reached the crime to the judiciary. Most of them only imposed administrative penalties. The judiciary concluded a few environmental pollution crimes.

\section{CONCLUSION}

The criminal norm means has a vital role in the prevention and control of environmental risks. Through the improvement of environmental criminal legislation, it will increase the punishment of criminal acts such as environmental pollution and destruction of resources, treat the environment as life and let environmental destruction Pay the price to effectively protect the environmental public interest and the environmental interests of the people and ensure that the most perfect environmental criminal law in history is implemented in the strictest way so that the socialist cause can be stably and continuously developed.

\section{REFERENCES}

[1] Zhao Bingzhi, Chen lu. Research on the Criminal Law Legislation and Improvement of Contemporary Environmental Crime in China[J]. Modern Law Science, 2011(6).

[2] [German] Klaus Roxin. The general theory of criminal law in Germany [M]. Wang Shizhou, translated. Beijing: Law Press, 2005.

[3] Zhu Zhifeng. The Expansion of Environmental Protection and Qualification Punishment[J]. Administration and Law, 2012(11).

[4] Chen Hongbing. The promotion of the concept of vulgar crimes: Taking the crime of environmental pollution as the starting point[J]. Legal Science, 2017(6).

[5] Zhao Bingzhi et al. Comparative Study of Environmental Crime [M]. Law Press, 2004.

[6] Jiang Lixia. Value concept of ecological criminal law[J]. Journal of Heilongjiang College of Ecological Engineering, 2008(2)

[7] $\mathrm{Xu}$ Xiang. Protection of ecological environment by criminal law[J]. Chongqing Social Sciences, 2018(2).

[8] Jiang Wenxiu. The subjective mentality of the crime of environmental pollution [J]. Journal of National Prosecutors College, 2016(3).

[9] Rob White. Environmental Harm, Ecological Justice and Crime Prevention[D]. University of Tasmania, 2007.

[10] Gao Mingxuan, Ma Kechang. Criminal Law (Seventh Edition) [M]. Beijing: Peking University Publishing, 2015.

[11] Wang Canfa. "The Connection of Two Laws" Promotes the Protection of Ecological Environment Criminal Law [N]. Proceedings Daily, 2017-3-12.

[12] An Keying. Basic Issues of Ecological Criminal Law [M]. Beijing: Law Press, 2014. 